Published on Reviews in History (https://reviews.history.ac.uk)

\title{
Portrait of a Party: The Conservative Party in Britain 1918-1945
}

Review Number: 1652

Publish date: Thursday, 11 September, 2014

Author: Stuart Ball

ISBN: 9780199667987

Date of Publication: 2013

Price: $£ 87.00$

Pages: 608pp.

Publisher: Oxford University Press

Publisher url: http://ukcatalogue.oup.com/product/9780199667987.do

Place of Publication: Oxford

Reviewer: Andrew Thorpe

It was once a truism of modern British historiography that the history of the Conservative party was grievously understudied. This has not been the case for some time: things began to change with the pioneering work of the late John Ramsden in the 1970s, and then from the 1980s as historians such as Philip Williamson began to offer significant reassessments of aspects of the party's past. A key intervention came in 1988, when Stuart Ball published Baldwin and the Conservative Party on the party's period of crisis in opposition to the second Labour government (1929-31). That book was important not just in its findings, but also in its method: it sought to use archives from every layer of the party, and, in particular, made very considerable use of constituency association records to advance its case that the severity and timing of the crisis had been significantly misjudged in the existing literature as a result of too narrow a source base. Ball has since established himself as a key figure in the field, through a series of works including the hefty coedited volume Conservative Century in 1996, as well as two volumes of diaries of the gloomy northern Conservative MP and junior minister, Cuthbert Headlam.

The present volume builds impressively on those achievements. It does so, in part, through length alone - at 300,000 words and almost 600 pages, this is not a volume for those light in attention span. But that is not the whole story. Ball has spent more than 30 years tracking down primary sources, and uses material from a total of 215 constituency bodies across England, Scotland and Wales, more than a third of the number of inter-war parliamentary constituencies, as well as the party's national-level records and the papers of all the prominent, and many of the not so prominent, Tory politicians of the day. More than that: he has brought all this together with a very clear conceptual framework to offer the most thorough history thus far of any 20thcentury British political party.

The book is divided into seven chapters which move concentrically inwards from the nature of Conservatism, through the general public, and the constituency and national-level organisation, and then towards the parliamentary party and ministers, before finally focussing on the party's leaders. Ball sums up the volume with an analysis of the sources of Conservative strength in the period.

Ball makes the point well that this was very much an era of Conservative strength. The inter-war period saw the rise of competing ideologies, and, in Britain, the rise of the Labour party. But the fact remains that the 
Conservatives achieved a plurality of votes at all seven of the general elections held between 1918 and 1935 . In only one election - 1929 - did they fail to emerge as the largest party in parliament, and even then Labour (with fewer votes than the Conservatives) could only form a minority government. Four of those seven elections between 1918 and 1935 can be characterised as Conservative landslides (even if three of them were won as part of coalitions). The election victory of 1924, won after a mere nine months of minority Labour government, was and remains the largest parliamentary majority ever won at an election fought on party lines (greater than the Liberal victory of 1906 or the Labour ones of 1945 and 1997). That of 1931, won after just over two years of Labour in office, saw the biggest landslide in British electoral history, with 470 Conservatives elected as part of the National government's 554 MPs as against Labour's 46. Put like this, though, we can miss a lot of the subtlety and nuance of the Conservative mood, which was not always as optimistic as the figures might suggest it should have been, and it is Ball's task to try to interrogate, not just the bases of Conservative strength, but also the reasons for the doubts that often assailed the party and its members.

The first chapter attempts to define Conservatism as it existed in the period. This is no easy task. Perhaps it is here that he is on least familiar ground. His source materials are diffuse. He makes good use of books, pamphlets, speeches and constituency records to try to bring out the key elements of the doctrine. His ultimate argument is that there was a basic ideological unity underpinning the party and its identity. This helped to keep the party together, and meant that secessions were rare. Most of the arguments within the party in this period, he suggests, were about strategy, methods and timing, and not about fundamental principles. Of course, the emphasis between the different elements of the ideology could vary between different Conservatives, and, over time, for the same Conservatives. But, at root, 'the Conservative Party in this era was not ideological in ethos or practice but there was a recognised and understood Conservatism which gave its adherents common ground and mutual empathy' (p. 9). This relied on a shared belief that change should only come when necessary, and that evolutionary change was better than revolutionary change; that 'reason' was not, in itself, a sufficient argument for change; that society evolved organically, and that human nature was not necessarily perfectible. This, in turn, meant that the Conservatives believed in the rights of property, the importance of authority and order, cross-class integration to at least a certain extent (reflected in a willingness to pass 'practical and undogmatic' measures of social reform (p. 30), religion (and particularly the Church of England), and private enterprise. However, they were not doctrinaire free marketeers, and could see a role for the state in many areas of life, including the economy, if industry deemed it appropriate. They were committed to national unity, although quite prepared to divide the nation to create that unity against a real or perceived internal threat, and were also committed to Britain's great power status and the Empire that was felt to sustain it. For Ball, Conservatism was a temperament, a spirit often characterised by pessimism above all else. What it meant for the average Conservative was a sense of duty, an ethical code deriving from Christian principles, respect for tradition, a commitment to national (although not, he suggests, racial) identity, patriotism and national unity, local pride, and 'character'. As well as defining Conservatism positively in this way, he also includes an important section on 'Fears', which help to explain what the Conservatives were defining themselves against - these included national decline, 'socialism', trade unionism, moral degeneration, 'intellectuals', Liberals - against whom particular ire was reserved - and Jews, much of the party being characterised by a mild, but nonetheless real, anti-semitism. Ultimately, the chapter argues that it was this defining of Conservatism that gave the party its unity and purpose, and meant that it was well able to survive the various threats it faced in the period. It is a wideranging chapter, which makes its case well and at length, although at the end of it I did wonder whether much of the evidence in it could have been employed in a rather less favourable interpretation.

How did this Conservatism play out with the population at large? This is the central question in chapter two. His overall conclusion here is fair enough - that 'in the interwar period ... the Conservative appeal had more resonance for more people most of the time than did any of the alternatives' (p. 145). This might seem an obvious point, but it is worth making, and reinforces the trends in recent work which stress both the general feebleness of inter-war Liberalism and also the failure of Labour to fully 'replace' the pre-war Liberal party. The means by which Ball reaches this conclusion are painstaking and include not just analysis of national- 
level election results, but a very thorough analysis which looks at the language and projection of their appeal (which includes a good analysis of the press in the period) before plunging into a detailed discussion of the economic and social basis of Conservative support. This emphasis on class will not suit every critic, and might be particularly scorned by some adherents of 'the new political history'. However, many people still believe that, for all its limitations, social class remains a useful category of analysis, and Ball's detailed analysis of the 1931 Census stands him in good stead in coming to a series of conclusions about the nature of, and limitations on, Conservative support between the wars. The analysis mainly confirms what we already knew - the higher social classes cleaved very strongly towards the Conservatives, lower middleclass support was 'the backbone of the Conservative Party' (p. 107), and the party could make strong appeals to large numbers of working-class voters despite Labour's attempts to portray itself as the only rational choice for the workers. But Ball offers a fuller empirical base for those propositions than we have had hitherto. Ball also makes a strong case for extending the much-noted 'gender gap' (a common feature of opinion polls between 1945 and the 1980s, whereby a higher proportion of women voted Conservative than men) back into the inter-war period. There is also a strong analysis of the regional basis of Conservative support. Anyone wishing to offer alternative findings will have to conduct some serious empirical research. Ball does caveat his findings by showing that Conservatives at the time did not always see how strong their underlying position was; but he might have added to this more clearly than he does the fact that the strategists of all parties lacked good information as the basis on which to strategise: the absence of anything approaching serious psephology in this period was a (largely unrecognised) bane of the lives of political planners of all parties, and while the methods which were to become available from the late 1940s onwards were far from perfect, they were better than the melange of newspaper editorials, MPs' soundings of their associations, and society gossip that combined to influence political strategy for most of the period between the wars. Then again, had the Conservatives been less pessimistic and more bullish, they might also have been more confidently reactionary, with results that were unlikely to have made for a happier and more united Britain.

The third chapter focusses on the constituency associations. This is territory where Ball is very comfortable indeed, and the chapter is very clear and fluent. The constituency sources are not easy to use. When writing my most recent monograph, I used the records of around 120 Conservative constituency associations (as well as a similar number of constituency Labour parties, and a smaller number of Liberal associations). It took a very long time, and I was only looking at a period roughly from 1938 to 1946. Ball's achievement here, therefore, is staggering. These sources were not written with historians in mind - indeed, they were usually produced for scarcely anyone outside the meeting room at all. They were working records designed for the moment, often written in haste by people with lots of other things to do. To interrogate them for historical purposes is, therefore, hugely time-consuming, and logistically challenging, since they are not all conveniently collected at the British Library or the Bodleian, but spread far and wide across the country. The materials themselves are often low-grade ore, yielding little that is of any obvious immediate interest. Yet approached with clear research questions in mind, and pulled together in the way that Ball achieves here, they can be immensely valuable - and there is no other way into the reality of constituency-level organisation. The chapter opens with a discussion of constituency-level officers, focussing especially on the often fraught relations between chairmen, agents and candidates. He then looks at branches and sections (where a division between men's and women's associations was maintained in most parts of the country prior to 1939/40), and membership (where he extrapolates from constituency records and other sources to suggest a total party membership of around 1,577,000 in the in the late 1920s and 1,247,000 between 1936 and 1939). The section on agents and woman organisers is very insightful, as is that on association finances, where he shows the considerable variations that existed between the fortunes of different associations. The section on candidate selection shows, while money alone was not enough to get a person selected as a candidate, most people were very unlikely to be selected without it, a position which Central Office was trying hard to change by the later 1930s, although with only limited results. The chapter ends with two really revealing sections. One is on the relationship between associations and MPs, which shows, inter alia, that an MP who clashed with his or her constituency chairman almost invariably came off worst. The other shows the extent and limitations of constituency pressure within the party as a whole, with some importance being 
accorded to constituency views in areas like the fall of the Lloyd George Coalition in 1922, help for agriculture, tariffs, and economy, but less so in the areas of India in the early 1930s or appeasement later in the decade. What the chapter does show, however, is that a Conservative leader, to be successful, had both to heed and to harness the constituencies. It was very dangerous to say that they did not matter, or - as in the case of Austen Chamberlain in 1922 - to give the impression that this was the leader's view.

In chapter four, the focus moves onto the national-level bodies of the party - the National Union, which was at the head of the voluntary party, and the party's headquarters at Central Office. Ball delineates effectively the roles of the constituencies and the regions, while also showing that the party conference, organised by the National Union, was of more importance than has generally been recognised. He offers a very detailed account of life at Central Office, with particular attention to key figures such as Sir Robert Topping, the principal agent/general director of the party from 1928 to 1945. Ball offers a clear sense of what happened at Central Office in good times and bad, and how it managed matters such as propaganda and publications. Finally, he really gets to grips with party funding. It is astonishing that the most thorough account of party finance in this period remains a book published in 1981 which, while an excellent pioneering work, is certainly not the last word. Ball's contribution here is very clear, offering details of annual income and expenditure, and giving a clear sense of the opportunities and challenges involved in funding the party. In an era when political parties seem to lunge from one financial crisis to another, with very little by way of serenity in between, modern day party organisers might consult Ball for a guide as to how a party could raise, but also spend, a lot of money while remaining on roughly an even keel.

Chapters two to four, then, are very much about the party outside Westminster. But attention shifts towards parliament in the final three chapters of the book. In chapter five, the emphasis is on the parliamentary party. Here, Ball shows that the social base of the party at Westminster changed relatively little over the period, other than that the proportion of landowner MPs fell significantly (although still remaining around 10 per cent at the end of the period). Lawyers remained the largest group, and grew a little more as a proportion, and there was a slight increase in those engaged in commerce and industry. There were very few workingclass MPs, and even those who were claimed as such often had a rather more complex story than such a categorisation would really allow. The was only one Conservative woman MP in both 1919 and 1945, but there were some larger totals in between, most notably in 1931, when victory in a number of apparently 'unwinnable' seats brought forth a bumper crop of 13 women MPs. Even this, of course, was a tiny proportion of the whole, and Ball makes it clear that it was tough being a Conservative woman outside the more commonly accepted categories of member, woman organiser, or candidate' s wife. Ball also offers a full and thoughtful discussion of the social side of Westminster life, and discusses backbench groups such as the YMCA in the 1920s and the Tory Reform Committee in the Second World War. He even essays some analysis of the whips, the most unknowable group in many ways, given the way that their work combined the utterly routine with the clandestine. He explains the origins of the 1922 Committee more clearly than any previous general account, and also offers some briefer comments on the House of Lords, doing enough to show at any rate why Lords reform was rarely thought a priority during the inter-war period.

Those who like their political history to be the history of 'great men' might be best to start with chapter six, which focusses on ministers, although it would be a stretch to describe some of the names involved as in any way 'great'. Ball offers a full analysis of the ways in which people attained office, and gives a rather sobering account of junior office - where many careers, such as that of Headlam himself, reached their rather unsatisfactory climax. The bulk of the analysis, though, focusses on the cabinet level. Ball offers an insightful appraisal of life as a cabinet minister, which was often far from glamorous. As if proving that this was no golden age of expert ministers and deliberative cabinets, against which more recent governments should be judged, Ball shows that ministers frequently struggled to get on top of their briefs, and that cabinet meetings tended to be "a scramble to get through an agenda" in which the focus was inevitably short term and departmentally oriented' (p. 411). In an attempt to show what made ministers successful or otherwise, he analyses in turn some of the leading figures of the party in this period, before offering fuller case studies of two of the Tory giants of the 1930s, Lord Halifax and Sir Samuel Hoare. This is a worthwhile exercise because it shows, more satisfactorily than previous scholarship, both why they rose as far as they did, and 
why they failed to attain the top job. In a section on cabinet divisions, Ball shows how relatively few cabinet ministers resigned in the period, before commenting on policymaking. The latter section is perhaps a little perfunctory in a book of this length, but it at least offers further insight into the Conservative Research Department and the exploits of its long-serving director, Sir Joseph Ball.

It is to Stuart Ball's credit that it is in the final chapter, and not the first, that attention turns to the five men who led the party in the period. He reminds us that there were no formal rules by which to select the leader, that there were no formal elections, and there was no set procedure for deselecting a leader or forcing a challenge to an incumbent. In a sense, things moved more subtly than that, reflecting Ball's earlier comments about the party as an organism rather than a machine. He is right to point out that 'no succession was ever truly guaranteed', so that 'not even the clearest heirs apparent could be sure that they would inherit' (p. 459). Indeed, as he might have added, in the case of Chamberlain (and later, Eden), long-standing heirs apparent could prove to be unsuccessful, and their terms of office short. It would have been interesting, though, to have seen Ball speculate a little on what would have happened had war not broken out in 1939. It is perhaps not Ball's style to do so, but what if (as seemed likely) the National government had won another election in autumn 1939, and Chamberlain had died when he did (late 1940), or retired after a year or two? With Halifax in the Lords, and Eden and Churchill out of favour, who would have succeeded as leader? Kingsley Wood? Perhaps even Hoare, despite Ball's earlier comments about his unsuitability? Or would it have been a case of someone unimaginable coming to the fore, as had been the case with Baldwin, a fairly obvious choice in 1923 but unthinkable three years earlier? It would have been useful to get a sense of Ball's views on this, if only because it might have offered some indication of just how far he believes the war changed the course of the party's history. Instead, the chapter goes on to offer a very clear delineation of the role and duties of the leader, before attempting a typography of Conservative leaders' style. He argues that there are three, at times overlapping, categories of leader. Of these, Law and Baldwin were 'honest and modest', like Douglas-Home and Major; Neville Chamberlain, 'decisive and dominant', like Heath and Thatcher; Churchill a 'charismatic hero', like Eden and Macmillan; and Austen Chamberlain, as always harder to place - honest but aloof, decisive but not dominant - a fact which Ball suggests helps explain why he was the party's shortest-lived leader. Some of the chapter's themes are then traced in greater detail by reference to four major crises - the revolt against the Coalition culminating in the Carlton Club meeting in 1922; the crisis of 1929-31; the crisis over India leading up to the 1935 Government of India Act; and the rumblings against Appeasement from 1936 onwards. Ball concludes the chapter by suggesting what made a leader successful or otherwise: ultimately, like Heath and Thatcher, the Chamberlain brothers were both too inflexible and domineering, whereas Law, Baldwin and Churchill 'were far more consensual and cautious as leaders, and had a much more subtle understanding of their interaction with the party that they led' (p. 506). Like all good leaders, they recognised that it was not just a matter of telling people what to do. They did not overestimate the powers of a leader, and were in their rather different ways good at the 'soft skills' of leadership that differentiate the true leader from the mere boss.

In his conclusion, Ball suggests that the Conservative party in this period had eight key strengths that made it the dominant force in politics. These were a 'basic consensus on principles' (p. 518); 'the underlying Conservative temperament' (p. 518); 'flexibility and pragmatism of methods' (p. 519); organisational resources based on the party's membership and wealth; the party's social and cultural cohesion; its 'instinct for unity' (p. 520); a clear chain of command and 'focus of authority in the leader' (p. 521); and, finally, 'a moderate and centrist strategy' on the part of the leadership (p. 522).

It detracts nothing from the quality of this volume to suggest that there are places where this reviewer would have offered differing emphases, approaches or content. No two historians would ever write the same book, after all. But there are some points of possible criticism or comment.

First, the thematic approach is really good for offering close analysis, but perhaps does not always give us enough on change over time. It is perhaps arguable that, in places, the 'portrait' is a little too static, a fact which is rather emphasised by the relative lack of attention to the period after 1940, when perhaps more was happening than Ball allows. This might not have been such an issue if each chapter had had a stronger 
overall conclusion, offering a more integrated feel. Secondly, Ball could be seen as being a little gentle in his view of the Conservatism of this period. It emerges pretty much as Conservatism as it was defined by Stanley Baldwin. While this is fair enough in the sense that Baldwin was leader of the party for half the period covered by the book, it does, perhaps, lead to a downplaying of what seem, to modern eyes, the less seemly aspects of Conservatism in the period. While some of these attitudes - for example racism, and particularly anti-semitism - are not ignored, they could perhaps have been investigated rather more fully in places. Thirdly, more might have been done to really bring out the nature of some of the big city Conservative machines. They are not ignored, but it would have been good, for example, to have had a fuller and more concentrated analysis of local boss Sir Archibald Salvidge's machine in Liverpool. Similarly, the role of the Earl of Derby in Lancashire would have repaid fuller discussion. This leads on to a fourth point that, in places, more could have been said about the sociability side of constituency life. In particular, it would be interesting to know the extent to which Conservative associations and their members were networked into other local bodies, such as golf clubs, tennis clubs, masonic lodges, church societies, rotary clubs, and so on. As Ross McKibbin has argued, the pioneering work of Margaret Stacey on Banbury offered some really interesting and insightful points about this, and it would have been good to see Ball follow some of this up in more detail. Was the real business of the association done at its own meetings, in the bar afterwards, or even, to at least some extent, somewhere else entirely? Fifthly, one grouse that might be unique to this particular reviewer is that Ball might have discussed the Second World War period in more depth. The war is not ignored, of course, but Ball does perhaps subscribe a little too readily to the idea that activity closed down, when it seems clear to me that this was something of a post hoc rationalisation for the party's heavy defeat in 1945. Sixthly, there could be more comparative comment. This might seem a churlish comment, given the staggering empirical achievement that this book represents. But some sense of why the Conservatives did things in the way that they did, when Labour and the Liberals did things the way they did, might have helped the analysis still further, and enabled the crafting of a still more persuasive argument about Conservative dominance in the period.

The final comment, which follows on from this, is that a little more could have been said about exogenous factors. Were the Conservatives fortunate, for example, in the elections they lost? In particular, 1929 was not a bad year to be ousted from power, as Ramsay MacDonald's Labour party was to find. To posit another counterfactual: what if the Conservatives had won in 1929 (as most people expected them to do)? Nothing they could have done would have obviated the economic crisis that was to follow later in 1929. Baldwin struggled badly enough in 1929-31 while in opposition - how much harder might he have found it in government? The possibility of a Conservative government presiding over growing economic crisis, without any credible policies on hand to deal with it, and with a Labour opposition moving to the left as the 'crisis of capitalism' became a reality, might have led to a very different outcome as the Conservatives overthrew Baldwin and brought in a more right-wing leadership prepared to make 'tough' decisions. Where this might have ended we cannot know, and it would be unwise to speculate further; but they key point is that, to some extent, the deliverability of Ball's eight strengths was in turn dependent on factors external to the party itself. In that sense, he might have offered a little more context than he did.

But that might have made an already long book even longer; and, in reality, the book as it stands does its job very well indeed. It shows, very effectively, how the different parts of the party related to each other; why they did so; and how this helped the party to be successful. It is, in that sense, a new kind of political history. It is not 'the new political history' in a way that would be recognised by the latter's adherents, but it is ' $a$ new political history' and it has every bit as much right as its showier precursor to be regarded as the template for future work. The challenge now is for historians of the Labour and Liberal parties to take a similar approach, and to produce an equally compelling 'portrait of a party'. What appeared to me at first as a rather unimaginative title turned out, 300,000 words later, to be just right: this is a portrait in the truest sense. It is as much a major contribution to historical method as it is to the history of 20th-century Britain.

The author is happy to accept this review and does not wish to comment further.

\section{Other reviews:}


Source URL:https://reviews.history.ac.uk/review/1652

Links

[1] https://reviews.history.ac.uk/item/62916 [2] http://blogs.lse.ac.uk/lsereviewofbooks/2013/08/16/bookreview-portrait-of-a-party-the-conservative-party-in-britain-1918-1945/ 